\title{
Ocena potencjału zasobowego CBM (coal bed methane) oraz możliwości występowania akumulacji gazu ziemnego typu tight w formacjach piaskowcowo- mułowcowych GZW
}

\begin{abstract}
W artykule przedstawiono wyniki obliczeń jednostkowego potencjału zasobowego metanu w pokładach węgla kamiennego niecki GZW (coalbed methane) oraz ocenę możliwości występowania akumulacji gazu ziemnego typu tight w formacjach mułowcowo-piaszczystych zalegających pomiędzy pokładami węgla. Zadanie zrealizowano, wykorzystując metodę dynamicznego przestrzennego modelowania 4D systemów naftowych przy użyciu oprogramowania PetroMod firmy Schlumberger. Modelowaniu poddano fragment karbońskiego wypełnienia niecki GZW o wymiarach $2,5 \times 2,5 \mathrm{~km}$, zlokalizowanego $\mathrm{w}$ jej południowo-zachodniej części. W ramach realizacji pracy skonstruowano przestrzenny dynamiczny model karbońskiego systemu naftowego, który był symulowany przy założeniach różnych scenariuszy ewolucji basenu sedymentacyjnego. Do budowy i kalibracji modeli wykorzystano dane dostępne w materiałach publikowanych, dane otworowe oraz wyniki badań laboratoryjnych próbek utworów karbońskich z odwiertów Jastrzębie-7b i Jastrzębie-8b, a także węgli kamiennych z KWK Zofiówka. W wyniku przeprowadzonych prac oszacowano jednostkowy potencjał zasobowy metanu w pokładach węgla kamiennego niecki GZW, wykazano zależność jego wielkości od typów węgli oraz przebiegu ewolucji basenu sedymentacyjnego niecki, a także oceniono możliwości występowania niekonwencjonalnych akumulacji typu tight $\mathrm{w}$ formacjach mułowcowo-piaszczystych.
\end{abstract}

Słowa kluczowe: potencjał zasobowy, formacja mułowcowo-piaszczysta, niecka GZW, złoże niekonwencjonalne, system naftowy.

Assessment of the unitary resource potential of coal bed methane and the possibilities of tight gas accumulations occurrence, in sandstone-mudstone formations of the Upper Silesian Coal Basin

The article presents the results of the unitary resource potential assessment of coal bed methane of the Upper Silesian Coal Basin (Coal Bed Methane) and an evaluation of the possibility of natural gas occurrences in tight, sandy mudstone formations interbedding coal seams. The task was carried out using the method of 4D dynamic petroleum systems modeling using the PetroMod software. Modeling tasks were carried for Carboniferous strata in the south-western part of the Upper Silesian Coal Basin, in the area of the Zofiówka coal mine. A spatial dynamic model (4D) of the Carboniferous petroleum system was developed, which was subsequently simulated assuming different scenarios for the evolution of the sedimentary basin. For model construction and calibration purposes, several data sources were used: well data of Jastrzębie-7B and Jastrzębie-8B wells, results of laboratory measurements of coal and rock samples from Zofiówka coal mine as well as published data. As a result, unitary estimation of the resource potential of coal bed methane of the Upper Silesian Coal Basin was presented, as well as its dependence upon the geological conditions of coal seams burial depths. The possibilities of the occurrence of unconventional accumulation of tight gas in sandy mudstone formations interbedding coal seams, were also indicated.

Key words: resource potential of coal bed methane, Upper Silesian Coal Basin, unconventional tight reservoirs, petroleum systems. 


\section{Wprowadzenie}

Węgiel jest skałą osadową powstałą $\mathrm{z}$ nagromadzenia szczątków organicznych w basenach sedymentacyjnych, które uległy przeobrażeniu w wyniku procesów fizykochemicznych spowodowanych wysokim ciśnieniem i temperaturą. Procesy te zachodzą najczęściej głęboko pod powierzchnią Ziemi, bez dostępu tlenu, i prowadzą do uwęglenia substancji organicznej (relatywnego wzbogacenia w węgiel pierwiastkowy), czemu towarzyszy wydzielanie się dużych ilości węglo- wodorów, w tym metanu. W tym kontekście pokłady węgla kamiennego mogą być rozpatrywane jako element systemu naftowego spełniający jednocześnie rolę skał macierzystych i zbiornikowych dla gazu. Wobec powyższych faktów do oceny możliwości występowania akumulacji gazu ziemnego w pokładach węgla oraz w formacjach mułowcowo-piaszczystych niecki GZW wykorzystana została metoda modelowania systemów naftowych, w której użyto oprogramowania PetroMod.

\section{Zastosowanie metody w odniesieniu do złóż niekonwencjonalnych}

Metoda modelowania systemów naftowych jest szeroko stosowana do oceny zasobów złóż konwencjonalnych i niekonwencjonalnych. Złoża te, $w$ tym również $\mathrm{CBM}$, posiadają wspólne cechy, ale występują pomiędzy nimi też pewne istotne różnice. Podobieństwo ich genezy w pewnych aspektach polega na tym, że powstają najczęściej w tych samych basenach sedymentacyjnych (rysunek 1), w wyniku takich samych procesów fizykochemicznych, źródłem ich są przeważnie takie same, a niekiedy nawet te same utwory macierzyste, mogą mieć taki sam skład mediów złożowych. Z tego względu procedury modelowania systemów naftowych, bez względu na ukierunkowanie poszukiwań na dany typ złóż, nie odbiegają od siebie, wymagają jedynie przesunięcia akcentów w zakresie detalizacji poszczególnych danych wejściowych $[2,6,19,20]$.
Zasadnicza różnica pomiędzy nimi wynika z faktu kumulowania się węglowodorów w odmiennych typach litologicznych skał, które stanowią różne elementy systemu naftowego, oraz najczęściej na różnych etapach ewolucji basenu sedymentacyjnego. O ile w przypadku prospekcji konwencjonalnych złóż węglowodorów przedmiotem zainteresowań są węglowodory, które po wygenerowaniu przez skały macierzyste uległy ekspulsji, migracji oraz akumulacji w skale zbiornikowej, to w przypadku poszukiwań złóż niekonwencjonalnych mamy do czynienia $z$ tą częścią węglowodorów, która została wygenerowana przez formację macierzystą i nie została z niej wydalona (pozostałość po ekspulsji).

Z faktów tych wynika, że o ile do utworzenia się konwencjonalnych złóż węglowodorów konieczna jest obecność

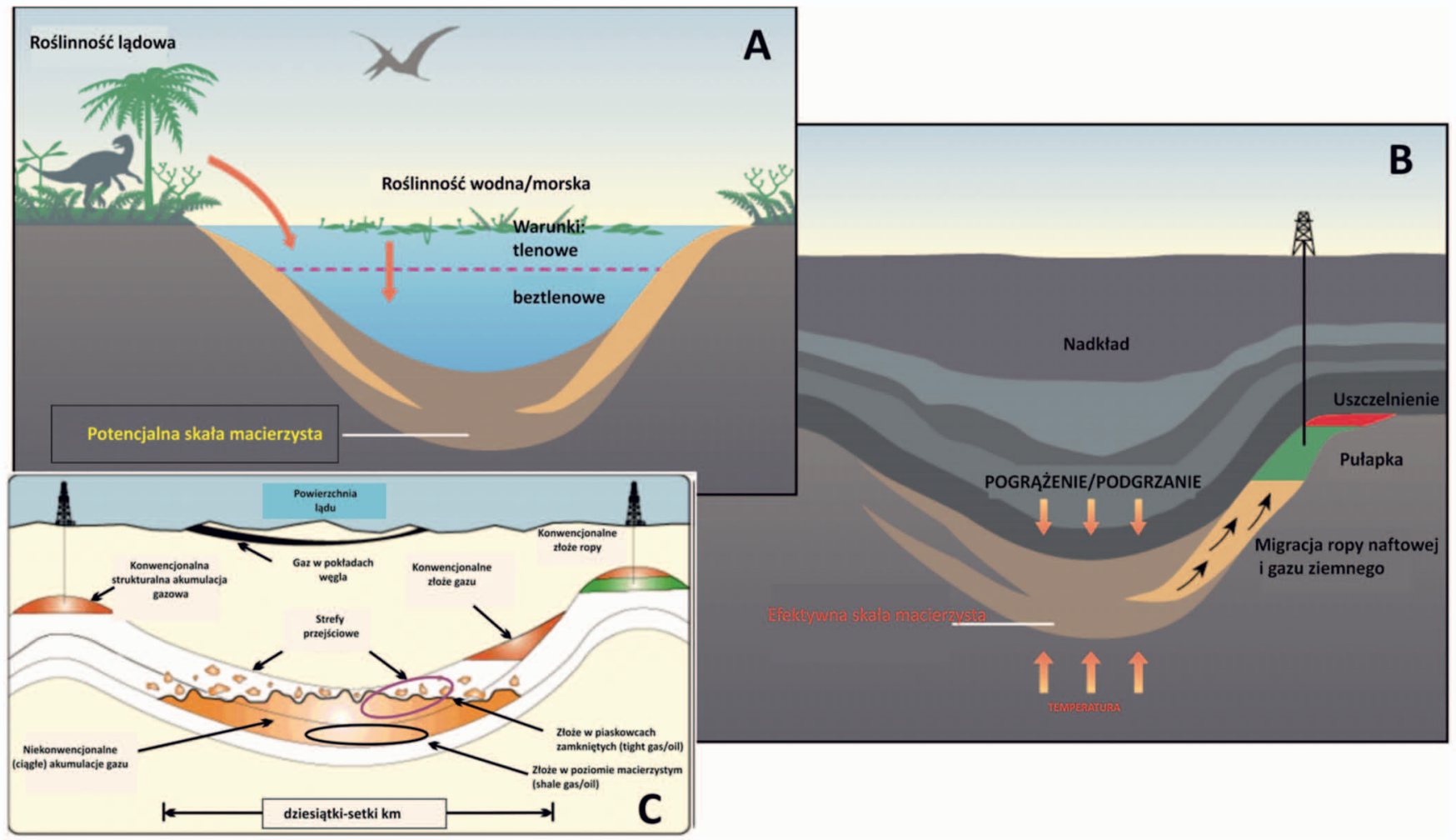

Rys. 1. Koncepcja systemów naftowych; etapy rozwoju basenu sedymentacyjnego: A - faza sedymentacji poziomu skał macierzystych; B - stan obecny; $\mathrm{C}$ - pozycja formacji niekonwencjonalnych $[1,8]$ 
w basenie sedymentacyjnym wszystkich elementów systemu naftowego (poziomów skał macierzystych, przewodzących i uszczelniających) oraz zajścia w odpowiedniej koincydencji przestrzennej i czasowej procesów naftowych (generowania węglowodorów, ich ekspulsji, migracji, formowania się pułapek złożowych), o tyle do powstania niekonwencjonalnych akumulacji typu CBM wystarczy jedynie obecność pokładu węgla będącego na odpowiednim stopniu przeobrażenia termicznego, który z racji posiadania specyficznych właściwości może jednocześnie spełniać rolę skały macierzystej i zbiornikowej.

Odmienna litologia skał, w których występują akumulacje węglowodorów, sprawia, że posiadają one różne parametry zbiornikowe, geomechaniczne i geochemiczne (porowatość, przepuszczalność, sprężystość, kruchość, zawartość TOC itp.). Różne są też mechanizmy, które doprowadziły do akumulacji i zachowania obydwu typów złóż. Złoża konwencjonalne tworzą wolne, mobilne węglowodory, które przymigrowały ze skały macierzystej i zostały zakumulowane w przestrzeni porowej utworów charakteryzujących się relatywnie wyższą porowatością i przepuszczalnością czy też w szczelinach.

Niekonwencjonalne akumulacje typu CBM występują w pokładach węgla, które charakteryzuje przekraczająca $90 \%$ zawartość TOC oraz relatywnie wysoka porowatość, w dużej mierze uzależniona od stopnia uwęglenia [13]. Metan występuje w nich in situ i stanowi produkt przeobrażenia termicznego materii organicznej. Jest on obecny głównie w mikroporach i nanoporach wykształconych w kerogenie. Mikropory i nanopory rozwijają się wraz z transformacją termiczną kerogenu na skutek jego konwersji do węglowodorów. Powstaje w ten sposób nie tylko dodatkowa przestrzeń akumulacyjna, ale także powierzchnia sorpcyjna dla węglowodorów [5]. Generowane lub powstałe na skutek wtórnego krakingu węglowodory gazowe w pierwszej kolejności sorbowane są na powierzchni, a ich nadmiar wypełnia nanopory i mikropory w kerogenie [6]. Specyfika złóż typu CBM wymusza konieczność wprowadzenia na etapie projektowania prac poszukiwawczych pewnych korekt, które dotyczą odpowiedniego doboru metod badawczych, weryfikacji rodzaju oraz zakresu analiz laboratoryjnych, a także opracowania metodyki interpretacji wyników przeprowadzonych pomiarów, oraz determinuje dobór metod udostępniania i eksploatacji odkrytych akumulacji. $Z$ tego też powodu stosowane są różne kryteria oceny ryzyka poszukiwań i rentowności wydobycia w odniesieniu do obydwu typów akumulacji.

Profesjonalnie przeprowadzone modelowanie systemu naftowego wymaga zastosowania szerokiego wachlarza da- nych geologicznych, termicznych, petrofizycznych, geochemicznych, geofizycznych, sedymentologicznych i innych, ale im większy zakres danych zostanie wykorzystany, tym większe prawdopodobieństwo rzetelnego odtworzenia przebiegu pełnego spektrum procesów zachodzących w basenie sedymentacyjnym, których skutkiem mogą być akumulacje węglowodorów występujące zarówno w postaci złóż konwencjonalnych, jak i niekonwencjonalnych. Tak więc oczekiwania odkryć konkretnych typów złóż węglowodorów nie narzucają ani stosowania odmiennych metod, ani też znaczących różnic w podejściu do modelowania systemów naftowych, ale wymagają wprowadzenia pewnych korekt, dotyczących przede wszystkim danych wejściowych, oraz analizy otrzymywanych wyników modelowania.

Jeśli chodzi o dane wejściowe, to w przypadku modelowania systemów naftowych pod kątem obecności złóż konwencjonalnych równie ważne są parametry (modele litologiczne) definiujące skały macierzyste, jak i zbiornikowe czy też uszczelniające, a także przebieg ewolucji tektonicznej, strukturalnej i termicznej basenu sedymentacyjnego w czasie geologicznym, determinujących przebieg procesów generowania, ekspulsji, migracji i akumulacji węglowodorów.

Jeśli chodzi o akumulacje niekonwencjonalne, a zwłaszcza CBM, szczegółowa charakterystyka obejmować powinna przede wszystkim interwały głębokościowe zawierające skały macierzyste oraz pokłady węgla i dotyczyć oceny rezydualnego potencjału węglowodorowego, parametrów petrofizycznych, a także stopnia przeobrażenia termicznego materii organicznej, determinujących objętość dodatkowej przestrzeni akumulacyjnej i powierzchni sorpcyjnej dla węglowodorów w węglu.

Ze względu na fakt, że akumulacje w pokładach węgla stanowi metan, występujący w postaci zaadsorbowanej na powierzchni mikroporów w węglu, konieczne jest na etapie przygotowania danych wejściowych do modelowania oznaczenie parametrów determinujących zdolność sorpcyjną węgli. Parametry te definiowane są przez izotermę Langmuira określającą stan równowagi pomiędzy gazem zaadsorbowanym i wolnym w stałej temperaturze w funkcji ciśnienia. Do obliczenia ilości metanu zaadsorbowanego w skale w określonych warunkach złożowych (ciśnienia, temperatury i przy danej zawartości TOC) konieczna jest znajomość parametrów, które oznaczane są na drodze eksperymentów laboratoryjnych. Są to: objętość Langmuira (objętość metanu zaadsorbowana przy maksymalnym ciśnieniu) i ciśnienie Langmuira (ciśnienie, przy którym połowa gazu zaadsorbowanego uległa desorpcji). 


\section{Obszar badań - geologiczny model statyczny}

Z uwagi na trudności w pozyskaniu niezbędnej ilości kompleksowych danych dotyczących konkretnego fragmentu obszaru niecki w zakresie umożliwiającym sporządzenie dla niego kompletnego, przestrzennego modelu geologicznego obejmującego pełny profil utworów węglonośnych zbudowano model syntetyczny, do którego konstrukcji wykorzystano dane z obszaru górniczego kopalni JSW Zofiówka oraz publikowane dane z odwiertu Ruptawa IG-1.

Horyzontalny zasięg modelu stanowi kwadrat o wymiarach 2,5 km na 2,5 km. Górna jego część (od elewacji do spągu górnośląskiej serii piaskowcowej) odzwierciedla przestrzenną budowę geologiczną fragmentu obszaru górniczego kopalni JSW Zofiówka. Została ona skonstruowana na podstawie map eksploatowanych w niej pokładów węgla oraz danych z otworów, wierconych z powierzchni terenu i z poziomów wyrobisk górniczych, dlatego odwzorowuje rzeczywiste upady i miąższości poszczególnych warstw, jak również ich lateralną zmienność.

Druga część modelu (od stropu serii paralicznej do kul$\mathrm{mu}$ ) została zbudowana przy wykorzystaniu profilu litologiczno-stratygraficznego otworu Ruptawa IG-1 [15]. Głębokości zalegania poszczególnych warstw i pokładów węgla serii paralicznej w modelu obliczano przez kolejne dodawanie ich miąższości (stwierdzonych w odwiercie Ruptawa IG-1) do głębokości zalegania spągu utworów górnośląskiej serii piaskowcowej na obszarze górniczym kopalni Zofiówka. Na całej powierzchni modelu przyjmowano stałe ich miąższości, dlatego kąty i kierunki ich zapadania są identyczne jak spągu górnośląskiej serii piaskowcowej.

Zbudowany model (rysunek 2) składa się łącznie ze 198 warstw i rozpoczyna od miocenu, zalegającego na stropie karbonu, którego powierzchnia ma charakter erozyjny. Poniżej zalegają utwory karbońskie serii mułowcowej, w większości niebranej pod uwagę z punktu widzenia węglonośności. Następnie znajduje się interpretowany karbon węglonośny, w którego skład wchodzą:

- spągowa część serii mułowcowej - reprezentowana przez warstwy załęskie (westfal), z pokładami 403, 404, 406,

- górnośląska seria piaskowcowa - obejmująca warstwy rudzkie (namur C), z pokładami 407, 409, 410, 411, 412,
413, 415, 416, 417, 418, oraz warstwy siodłowe (namur B), z pokładami 505, 508, 510,

- seria paraliczna (namur A) - obejmująca warstwy porębskie, z pokładami 603, 605, 607, 610, 624, 625, 630, warstwy jakolowieckie, z pokładami 713, 723, warstwy gruszkowskie, z pokładami $839,842,846$, oraz warstwy pietrzkowickie, z pokładami 905 i 911.

Poniżej znajduje się nierozdzielona fliszowa facja kulmu (górny wizen i dolny namur). Podściela ją warstwa złożona $\mathrm{z}$ węglanowych utworów należących do wizenu, turneju oraz dewonu górnego i środkowego. Ostatnią warstwą modelu jest podłoże krystaliczne.

Łączna miąższość pokładów węgla w profilu wynosi w przybliżeniu $90 \mathrm{~m}$, z czego miąższość najcieńszych pokładów, występujących głównie w serii paralicznej, wynosi $0,5 \mathrm{~m}$, a najgrubszego ponad 4,5 m (pokład 411/1).

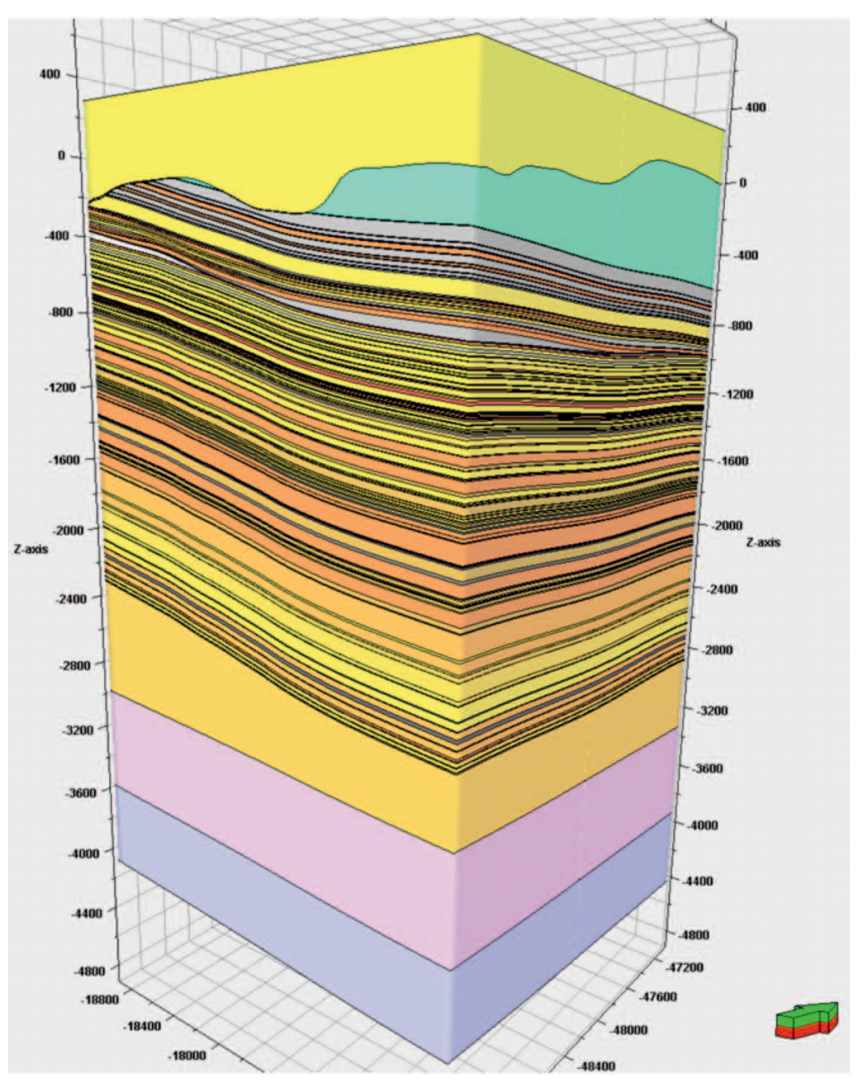

Rys. 2. Wizualizacja przestrzenna modelu strukturalnego obszaru badań

\section{Konstrukcja bazowego modelu dynamicznego}

Dla każdej warstwy wydzielonej na podstawie map głębokościowych zdefiniowano litotyp (fację) oraz wiek bezwzględny początku i końca sedymentacji [11]. Pokładom węgli dodatkowo przyporządkowano zdefiniowany model kinetyczny i oznaczone parametry geochemiczne. Modele litologiczne (litotypy) dla poszczególnych wydzieleń litologicznych pomiędzy pokładami węgla opracowano na podstawie interpretacji pomiarów (krzywych) geofizyki wiertniczej kalibrowanych pomiarami laboratoryjnymi, a wiek bezwzględny warstw zdefiniowano na podstawie tabeli stratygraficznej (według ICS, 


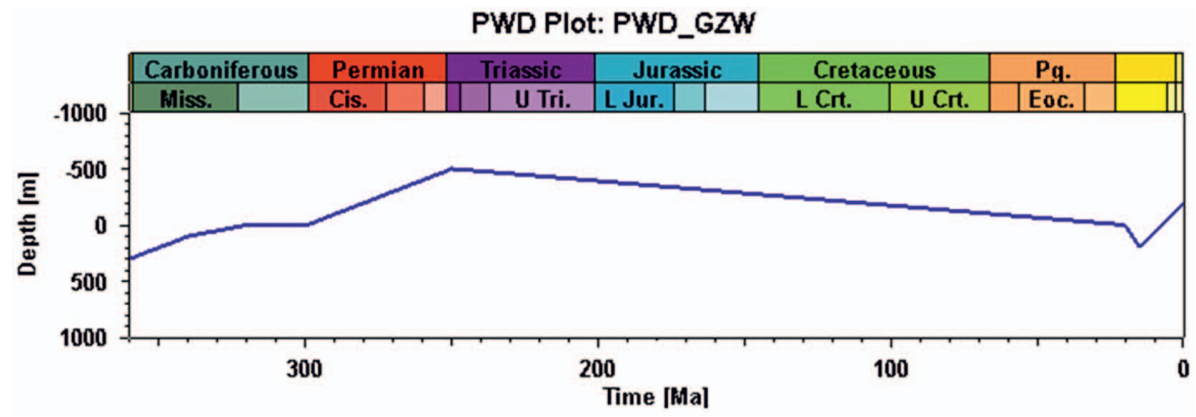

Rys. 3. Trend zmian paleogłębokości zbiornika sedymentacyjnego niecki GZW czego Ruptawa IG-1 [PGOW R1], obliczono wartość współczesnego strumienia cieplnego, która była zgodna $\mathrm{z}$ danymi publikowanymi $[7,12]$. Warunki brzegowe transportu ciepła definiowano wartościami paleostrumienia cieplnego oraz paleotemperatur kontaktu woda-osad (rysunek 4). Paleotemperatury kontaktu woda-osad w basenie niecki obliczone zostały na podstawie algorytmu zamieszczonego w pro-
2008) zawartej w edytorze programu PetroMod. Odtworzono i zaimplementowano do modelu trend zmian paleobatymetrycznych basenu niecki GZW (rysunek 3) oraz oszacowano miąższości zerodowanych utworów górnokarbońskich, a także wiek bezwzględny interwału erozyjnego.

Miąższość erozji pokarbońskiej szacowana była w oparciu o dane literaturowe [3,9], ale ostateczna jej wartość została przyjęta na podstawie wyników kalibracji zintegrowanych modeli (geodynamicznego i termicznego).

Wielkość erozji pokarbońskiej na obszarze GZW ma bezpośredni związek z maksymalnym pogrzebaniem utworów karbonu produktywnego wypełniających nieckę, co z kolei oszacować można w sposób pośredni - na podstawie pomierzonych obecnych porowatości efektywnych. Porowatość efektywna ksztaltowana jest w procesie kompakcji mechanicznej, kontrolowanym przez wartość maksymalnych efektywnych naprężeń, będących funkcją maksymalnego pogrążenia $[9,16,17]$. Zależności te zostały wykorzystane do oceny wielkości erozji pokarbońskiej. Pomierzone porowatości utworów klastycznych w profilu odwiertu Ruptawa IG-1 posłużyły jako dane kalibracyjne modelu pogrążania utworów niecki i miały ostateczny wpływ na wielkość oszacowanej erozji. Miąższość zerodowanych utworów na analizowanym fragmencie obszaru niecki oceniono na $2500 \mathrm{~m}$ - i nie odbiega ona znacząco od obecnie panujących w tym zakresie poglądów $[3,9]$.

Model termiczny obszaru konstruowano w powiązaniu z modelem geologicznym, uwzględniającym zarówno dynamikę subsydencji i wydźwignięcia obszaru, jak i parametry termiczne (ciepło radioaktywne, przewodność cieplną i pojemność cieplną) poszczególnych wydzieleń litologicznych (litotypów). Opierając się na publikowanym termogramie profilu głębokiego otworu wiertni- gramie PetroMod, uwzględniającego paleobatymetrię oraz model paleoklimatyczny [21]. W procesie kalibracji zintegrowanych modeli (opierając się na różnych przesłankach geologicznych) zakładano różne wersje ewolucji (zmienności w czasie geologicznym) wartości strumienia cieplnego $[18,22]$. Modele kalibrowano (dostępnymi w publikacjach) wartościami refleksyjności witrynitu $[13,14]$ oraz wartościami pirolitycznego wskaźnika dojrzałości termicznej $T_{\max }$ węgli kamiennych. Najlepsze dopasowanie krzywej teoretycznej do punktów wartości pomiarowych (dla przyjętej erozji pokarbońskiej utworów stefanu wynoszącej $2500 \mathrm{~m}$ ) uzyskano przy założeniu stałego (niezmiennego w czasie geologicznym) strumienia cieplnego w wysokości $70 \mathrm{~mW} / \mathrm{m}^{2}$.

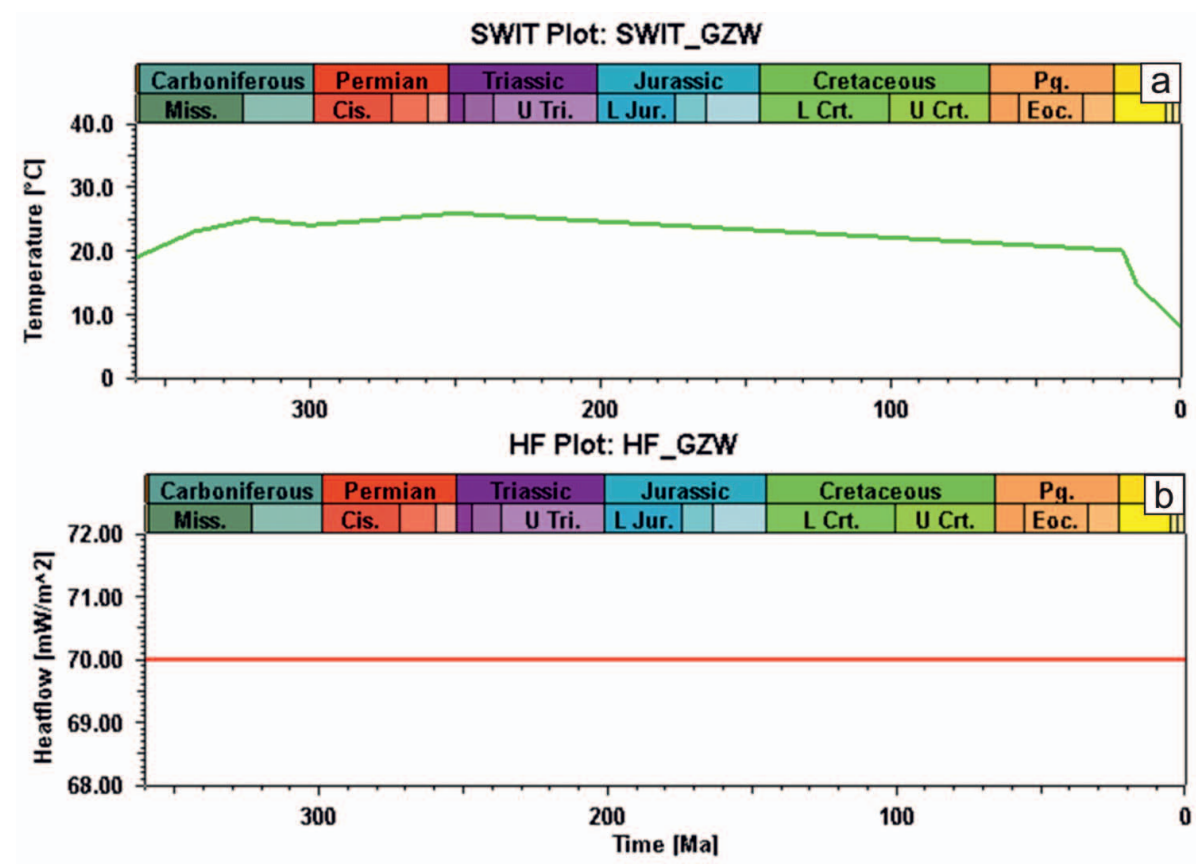

Rys. 4. Parametry brzegowe modelu termicznego: a) temperatura, b) strumień cieplny

Parametry geochemiczne węgli oznaczono w INiG - PIB na podstawie wyników pomiarów analizy pirolitycznej Rock-Eval próbek węgli pobranych z pokładów 411, 412, 413 z wyrobisk kopalni Zofiówka. Stopień ich przeobrażenia termicznego wyrażony wartością wskaźnika pirolitycznego $T_{\max }$ wynosił $466 \div 470^{\circ} \mathrm{C}$, co w skali refleksyjności witrynitu $R_{o}$ odpowiada 
wartościom $1,28 \div 1,30 \%$. Zawierają one około $85 \%$ węgla pierwiastkowego (TOC). Pomierzona wartość jego rezydualnego potencjału węglowodorowego $\mathrm{HI}$ wynosi 90 $\div 100 \mathrm{mg} \mathrm{HC} / \mathrm{g}$, co pozwala oszacować wartość jego inicjalnego potencjału $\mathrm{HI}_{0}$ na około $200 \mathrm{mg} \mathrm{HC} / \mathrm{g}$ TOC.

Model kinetyczny węgli, który został przyjęty w modelu symulacyjnym, opracowany został na podstawie oznaczeń rozkładu energii aktywacji węgli z Zagłębia Ruhry [10] i przeznaczony jest do symulacji generowania metanu z pokładów węgla kamiennego. Model adsorpcyjny (parametry Langmuira) dla węgli GZW opracowany został na podstawie krzywych izotermy sorpcji metanu [4] wykonanych na próbkach z pokładów 412 i 413 z niecki GZW (rysunek 5).

Bazowy model symulacyjny skalibrowany został średnimi wartościami porowatości wyinterpretowanymi dla poszczególnych wydzieleń litologicznych w profilu odwiertu Jastrzębie-7b oraz pomiarami stopnia przeobrażenia
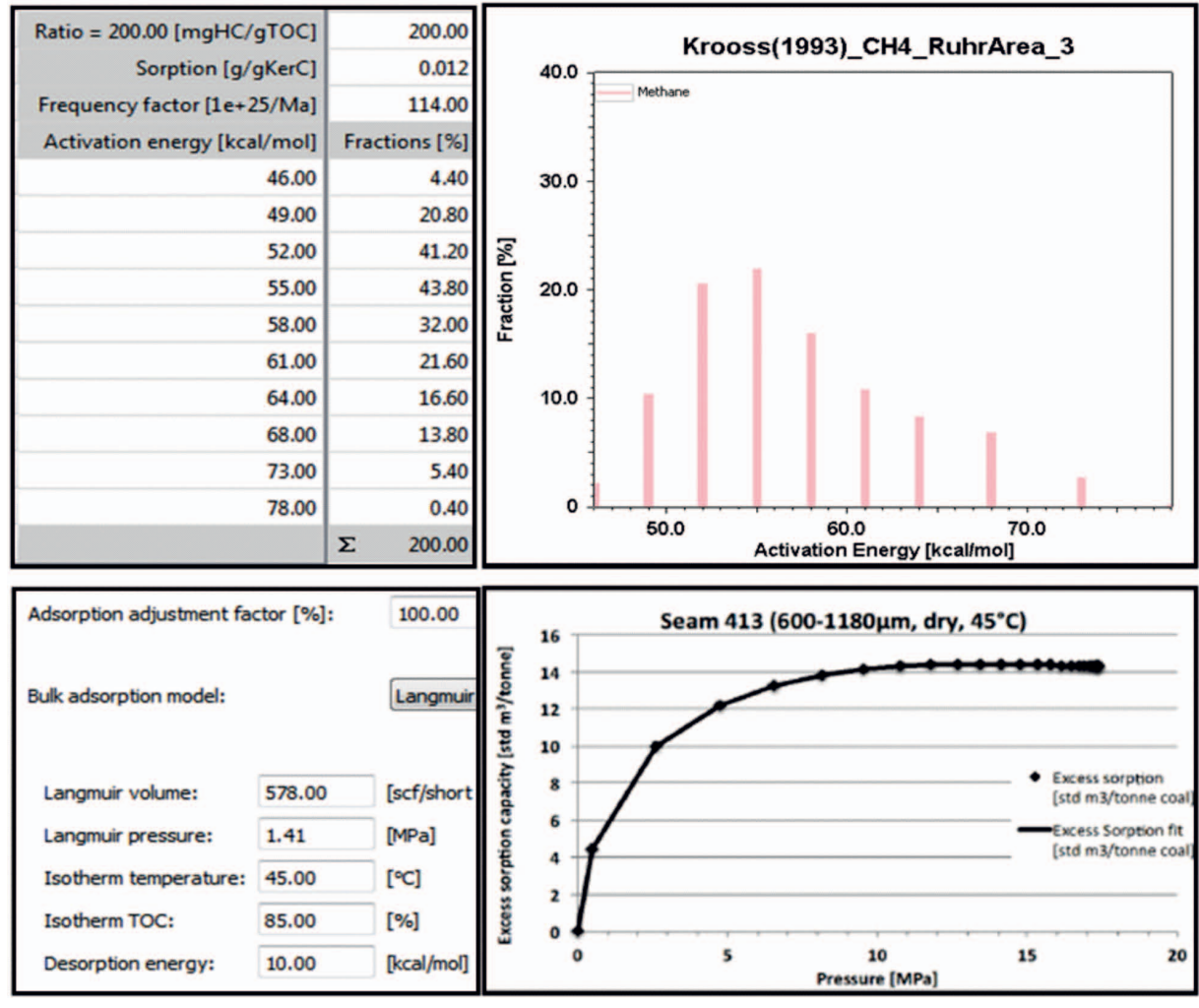

Rys. 5. Model kinetyczny i sorpcyjny węgla przyjęty w modelu symulacyjnym systemu naftowego niecki GZW

termicznego węgli z różnych pokładów i różnych odwiertów zlokalizowanych w różnych punktach niecki.

\section{Wyniki modelowania}

Modelowany obiekt stanowił niewiele więcej niż jedną tysięczną powierzchni całej niecki GZW, co w połączeniu ze skomplikowanym stylem jej budowy geologicznej nie upoważnia autorów do wyciągania wniosków dotyczących potencjału zasobowego CBM w stosunku do całej niecki. Jednakże autorzy pracy, mając na uwadze powyższe fakty, a jednocześnie chcąc poznać skalę procesów naftowych i ich końcowy efekt w zależności od warunków termicznych, dynamicznych, strukturalno-tektonicznych, zbudowali modele alternatywne będące modyfikacjami modelu bazowego, w których przyjęli odmienne, hipotetyczne wartości parametrów wejściowych, mogące odzwierciedlać warunki w innych rejonach niecki.

Skonstruowano i skalibrowano model bazowy GZW_0, a następnie utworzono jego cztery modyfikacje, z których każda symulowana była w dwóch wariantach: z otwartymi granicami basenu (w1) i zamkniętymi granicami basenu (w2). W ta- blicy 1 przedstawiono oznaczenia poszczególnych modeli i zakres ich modyfikacji w stosunku do modelu bazowego.

Inicjacja procesu generowania węglowodorów związana jest bezpośrednio z podgrzaniem warstwy zasobnej w substancję organiczną. W niecce GZW nastąpiło to na skutek pogrążenia na duże głębokości osadów zasobnych w substancję organiczną przy relatywnie wysokiej wartości (utrzymującej

Tablica 1. Oznaczenia poszczególnych modyfikacji modelu bazowego i ich zakres

\begin{tabular}{|c|l|}
\hline Model & \multicolumn{1}{|c|}{ Opis zmian założeń w stosunku do modelu bazowego } \\
\hline GZW_0_w1 & Skalibrowany model bazowy - otwarty \\
\hline GZW_0_w2 & Skalibrowany model bazowy - zamknięty \\
\hline GZW_1_w1 & Zwiększona zdolność sorpcyjna kerogenu - otwarty \\
\hline GZW_1_w2 & Zwiększona zdolność sorpcyjna kerogenu - zamknięty \\
\hline GZW_2_w1 & Wyższy reżim termiczny - otwarty (wyższy strumień cieplny HF) \\
\hline GZW_2_w2 & Wyższy reżim termiczny - zamknięty (wyższy strumień cieplny HF) \\
\hline GZW_3_w1 & Wyższy inicjalny potencjał węglowodorowy $\mathrm{HI}_{0}$ - otwarty \\
\hline GZW_3_w2 & Wyższy inicjalny potencjał węglowodorowy HI ${ }_{0}$ - zamknięty \\
\hline GZW_4_w1 & Wyższy reżim termiczny i ciśnień (pogrążenie) - otwarty \\
\hline GZW_4_w2 & Wyższy reżim termiczny i ciśnień (pogrążenie) - zamknięty \\
\hline
\end{tabular}


się do czasu obecnego) gęstości strumienia cieplnego podłoża. W związku z powyższym autorzy ograniczyli się do opisu przebiegu tych procesów w warstwie obecnie stanowiącej pokład węgla 412, w punkcie zlokalizowanym w centralnej części analizowanego obszaru na podstawie wyników symulacji modelu bazowego GZW_0. Przebieg tych procesów, zwłaszcza w zakresie czasu ich trwania, można uznać za reprezentatywny dla uzyskanych w wyniku symulacji pozostałych modeli.

Pod koniec górnego karbonu, po pogrążeniu osadów na głębokość około $3000 \mathrm{~m}$ i osiągnięciu temperatury około $100^{\circ} \mathrm{C}$, nastąpiła inicjacja procesów generowania węglowodorów. Dalsza intensywna sedymentacja utworów górnokarbońskich powodowała szybkie pogrążanie warstwy do głębokości około $3700 \mathrm{~m}$ i podniesienie temperatury do ponad $150^{\circ} \mathrm{C}$, wywołując dalszy wzrost przeobrażenia termicznego materii organicznej (do $1,25-1,30 \% \mathrm{w}$ skali refleksyjności witrytu $R_{o}$ ) i ilości wygenerowanych przez nią węglowodorów. W dolnym permie, na skutek wypiętrzania obszaru i intensywnej erozji osadów, temperatura w basenie zaczęła spadać - trend ten został zachowany do czasu obecnego. Na skutek spadku temperatury procesy termicznego generowania węglowodorów przez węgiel w pokładzie 412 praktycznie ustały już pod koniec permu (rysunek 6). Przebieg procesów naftowych w innych pokładach na tym obszarze był bardzo podobny, z tym że w głębiej zalegających, a więc i starszych, pro- cesy te inicjowane mogły być nieco wcześniej i przebiegać efektywniej.

Kolejne modyfikacje modelu bazowego uwzględniały zmiany wartości tych parametrów, które mogły mieć wpływ na końcowy efekt procesów naftowych, a nie na czas ich inicjacji czy też tempo ich przebiegu w poszczególnych interwałach czasowych. $Z$ tego powodu interpretacja wyników modelowania dotyczy głównie końcowych skutków tych procesów.

$\mathrm{Na}$ analizowanym obszarze zlokalizowano i wydzielono 48 pokładów węgla o łącznej miąższości około $90 \mathrm{~m}$ i średnich głębokościach zalegania w interwale $400 \div 2600 \mathrm{~m}$. Analizę porównawczą wyników symulacji poszczególnych modeli przeprowadzano w kontekście całych brył modeli (konkretnie ich karbońskiego wypełnienia), nie odnosząc się do poszczególnych pokładów węgla, czy też potencjalnych poziomów zbiornikowych (mułowcowo-piaskowcowych). Takie podejście wydaje się słuszne i uzasadnione brakiem de-

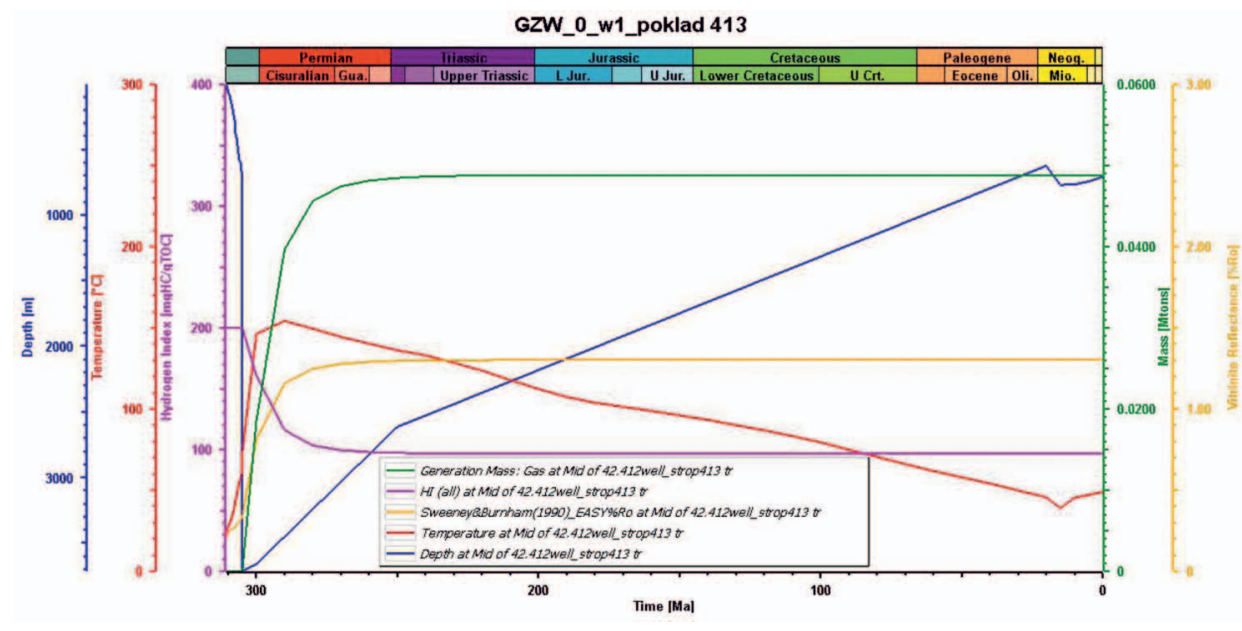

Rys. 6. Dynamika procesów naftowych determinowanych ewolucją basenu sedymentacyjnego niecki według scenariusza przyjętego w modelu bazowym GZW_0 (dla pokładu 413)

Tablica 2. Wyniki symulacji wszystkich modyfikacji modelu bazowego w obydwu wariantach [mln $\left.\mathrm{m}^{3}\right]$

\begin{tabular}{|c|c|c|c|c|c|c|c|c|c|c|}
\hline \multirow{2}{*}{ Model } & \multicolumn{2}{|c|}{ Potencjał generacyjny } & \multicolumn{4}{|c|}{ Zakumulowane w pokładach węgla } & \multirow{2}{*}{$\begin{array}{l}\text { Bilans } \\
\text { ekspulsji }\end{array}$} & \multicolumn{3}{|c|}{$\begin{array}{c}\text { Zakumulowane w skałach } \\
\text { zbiornikowych }\end{array}$} \\
\hline & $\begin{array}{l}\text { niezrealizo- } \\
\text { wany }\end{array}$ & zrealizowany & razem & $\begin{array}{c}\text { ropa } \\
\text { naftowa }\end{array}$ & $\begin{array}{c}\text { gaz } \\
\text { wolny }\end{array}$ & $\begin{array}{c}\text { gaz } \\
\text { adsorb. }\end{array}$ & & razem & $\begin{array}{c}\text { ropa } \\
\text { naftowa }\end{array}$ & gaz \\
\hline GZW_0_w1 & 80024 & 123368 & 4439 & 0 & 0,28 & 4439 & 118928 & 0 & 0 & 0 \\
\hline GZW_0_w2 & 79259 & 124133 & 22367 & 0 & 17981 & 4385 & 101765 & 427 & 0 & 427 \\
\hline GZW_1_w1 & 80028 & 123363 & 5002 & 0 & 0,28 & 5002 & 118360 & 0 & 0 & 0 \\
\hline GZW_1_w2 & 79220 & 124171 & 22816 & 0 & 17873 & 4943 & 101355 & 427 & 0 & 427 \\
\hline GZW_2_w1 & 58360 & 145036 & 3182 & 0 & 0,26 & 3182 & 141853 & 0 & 0 & 0 \\
\hline GZW_2_w2 & 57726 & 145669 & 23907 & 0 & 20769 & 3137 & 121762 & 415 & 0 & 415 \\
\hline GZW_3_w1 & 119807 & 185281 & 4367 & 0 & 0,40 & 4366 & 180914 & 0 & 0 & 0 \\
\hline GZW_3_w2 & 118489 & 186600 & 42946 & 0 & 38638 & 4308 & 143653 & 442 & 0 & 442 \\
\hline GZW_4_w1 & 59039 & 146084 & 3494 & 0 & 0,30 & 3494 & 142589 & 0 & 0 & 0 \\
\hline GZW_4_w2 & 58719 & 146405 & 24703 & 0 & 21249 & 3453 & 121702 & 420 & 0 & 420 \\
\hline
\end{tabular}


talicznych danych dotyczących zróżnicowania składu petrologicznego pomiędzy poszczególnymi pokładami węgla. $Z$ tego względu w obrębie poszczególnych modeli dla każdego z pokładów przyjmowano identyczne parametry geochemiczne, manifestujące się taką samą wartością inicjalnego wskaźnika wodorowego HI i jednakową zawartością węgla pierwiastkowego TOC. Wielkości tych parametrów przyjęto na podstawie wyników analiz laboratoryjnych przeprowadzonych w INiG - PIB na próbkach węgli z pokładów 411, 412, 413 kopalni Zofiówka. W jednej z modyfikacji modelu bazowego (GZW_3) hipotetycznie założono występowanie lepszych jakościowo węgli, o zwiększonym udziale macerałów egzynitowych, co skutkowało podwyższeniem wartości inicjalnego wskaźnika węglowodorowego $\mathrm{HI}_{0}$ do wysokości 300 mg HC/g TOC.

Różnice w założeniach pomiędzy poszczególnymi modyfikacjami modeli są niewielkie, ich wartości przyjmowane były raczej w zakresach średnich, realnych, a nie ekstremalnych, mało prawdopodobnych. Wyniki symulacji modelu bazowego i wszystkich jego modyfikacji świadczą o tym, że potencjał CBM niecki GZW jest bardzo wielki (tablica 2). Inicjalny potencjał węglowodorowy analizowanego obszaru, który ma powierzchnię $6,25 \mathrm{~km}^{2}$, wynosił ponad $200 \mathrm{mld} \mathrm{m}^{3}$ gazu (metanu).

Z symulacji każdego z modeli wynika, że początkowy potencjał generacyjny tych węgli został już w $60 \div 70 \%$ zrealizowany, co oznacza, że z tego obszaru wygenerowało się $120 \div 150 \mathrm{mld} \mathrm{m}^{3}$ gazu, ale tylko niewielka jego część została zakumulowana $\mathrm{w}$ granicach modelu.

Wyniki symulacji wszystkich modeli w wersji z ich otwartymi granicami nie wykazują obecności akumulacji gazu w wolnej postaci ani w poziomach macierzystych (pokładach węgla), ani w poziomach potencjalnych skał zbiornikowych (formacjach piaszczystych i mułowcowych). Według tych założeń gaz zakumulowany w utworach karbońskich występuje tu tylko w postaci zaadsorbowanej w pokładach węgla, a jego ilości zależą od zdolności sorpcyjnej, która jest definiowana przez parametry Langmuira. Taki stan rzeczy może wynikać z faktu, że na modelowanym obszarze, zajmującym małą powierzchnię, warstwy zalegają monoklinalnie, brak jest struktur mogących tworzyć pułapki i uskoków mogących stanowić ich zamknięcia. W takim przypadku wygenerowane węglowodory migrują wzdłuż warstw (przepuszczalność lateralna znacznie większa od wertykalnej) i ulegają rozproszeniu poprzez otwarte brzegi modelu. Aby sprawdzić możliwość powstawania złóż konwencjonalnych lub typu tight w poziomach mułowcowo-piaszczystych, zastosowano możliwą do wykorzystania opcję symulowania „z zamkniętymi brzegami modelu". Opcja taka pozoruje występowanie na modelowa-

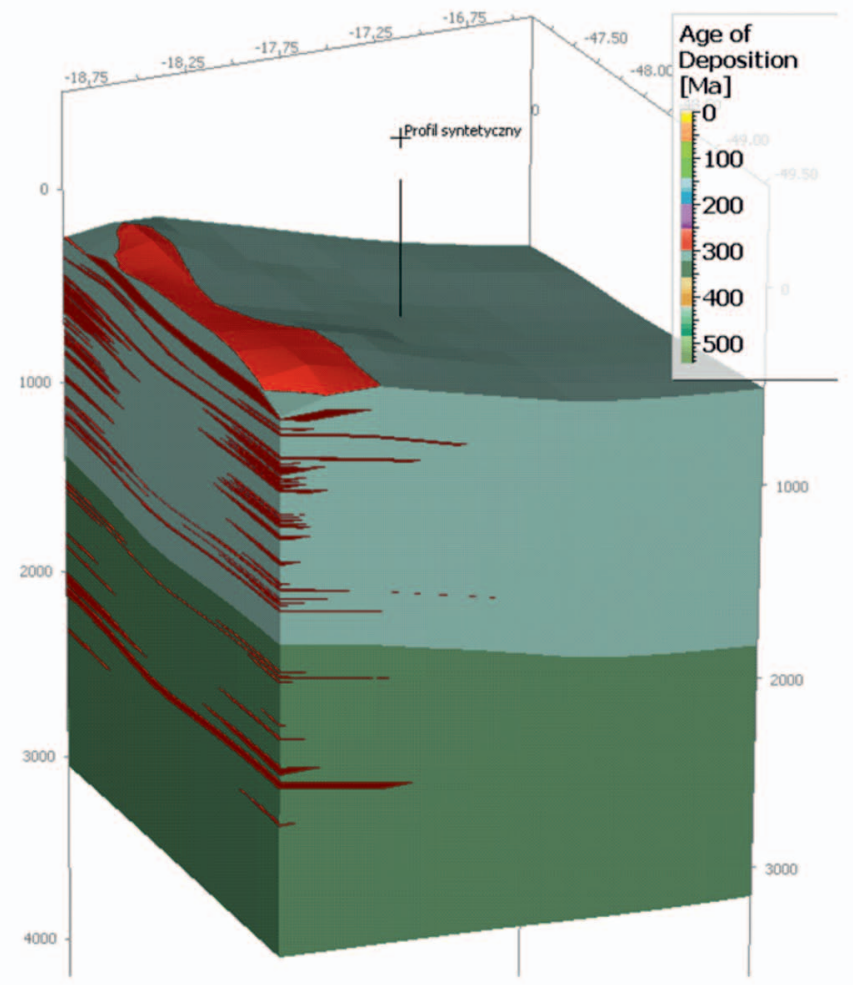

Rys. 7. Rozmieszczenie złóż w formacjach mułowcowopiaszczystych uzyskane w wyniku symulacji modelu bazowego z opcją zamkniętych brzegów modelu

nym obszarze pułapek, których zamknięcia stanowią granice modelu (rysunek 7).

Przy jej zastosowaniu rozproszenie wygenerowanych węglowodorów może następować tylko poprzez migrację pionową. Symulacje w tej wersji przeprowadzono dla wszystkich modyfikacji modelu bazowego. Ich wyniki wykazały, że ilości wolnego gazu kumulowanego w pokładach węgla na analizowanym obszarze mogą być bardzo duże i wynosić $22 \div 42 \mathrm{mld} \mathrm{m}^{3}$ oraz że możliwe jest napełnianie gazem poziomów mułowcowo-piaszczystych, a ilości zakumulowanego w nich gazu mogą przekraczać $400 \mathrm{mln} \mathrm{m}^{3}$. Co prawda nie są to znaczące ilości, ale należy również zwrócić uwagę na małą powierzchnię obszaru zasilania tych pułapek, gdyż zamknięcie brzegów basenu ogranicza nie tylko rozproszenie gazu, ale również jego dopływ. Ograniczenie ucieczki gazu wzdłuż warstw powoduje także duże nasycenie utworów drobnoklastycznych (rysunek 8).

W jednej z modyfikacji modelu bazowego (GZW_1) przyjęto nieco większą zdolność sorpcyjną węgli (taką, jaką oznaczono dla węgla z pokładu 412) w stosunku do pozostałych modeli (w których przyjęto model sorpcyjny węgla z pokładu 413). W wyniku symulacji tego modelu uzyskano od około $15 \%$ do prawie $60 \%$ gazu zaadsorbowanego więcej niż w pozostałych modelach. $\mathrm{Z}$ tego faktu wynika, że ilość gazu zaadsorbowanego zależy nie tylko od zdolności sorp- 
cyjnej węgla, ale również od warunków termodynamicznych oraz od historii termicznej basenu. Ilości, które zostały wyli-

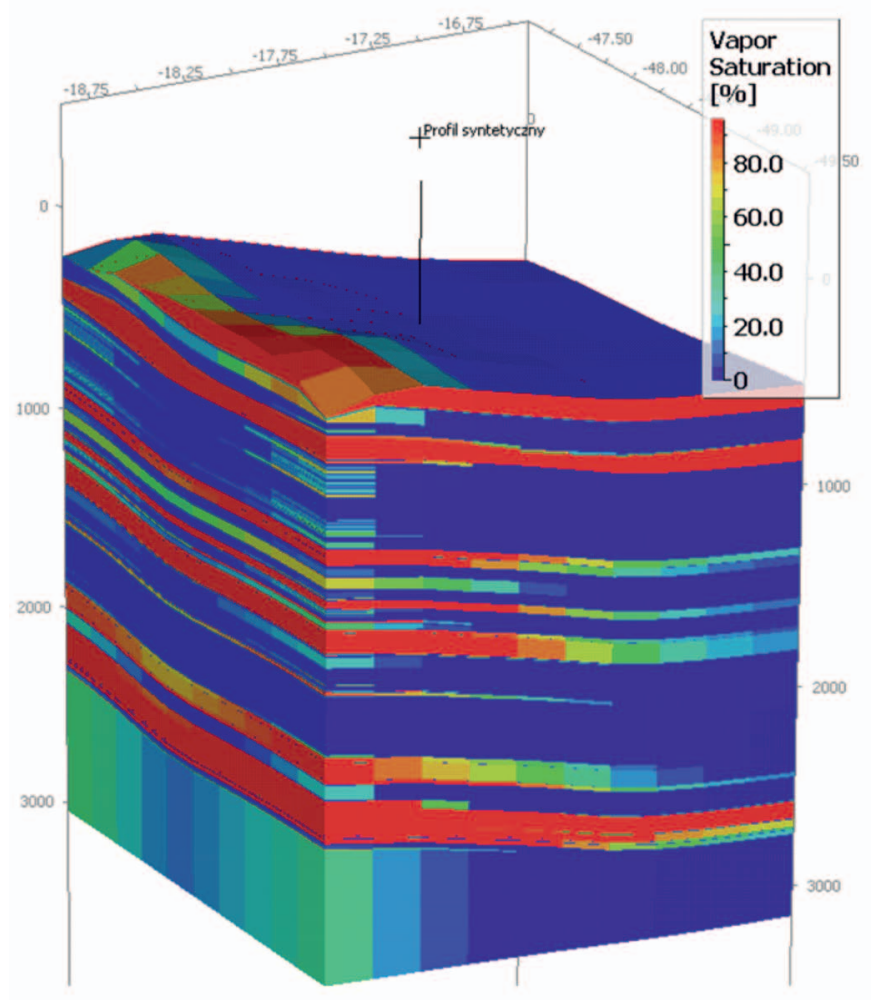

Rys. 8. Nasycenia gazem utworów karbońskich uzyskane w wyniku symulacji modelu bazowego z opcją zamkniętych brzegów

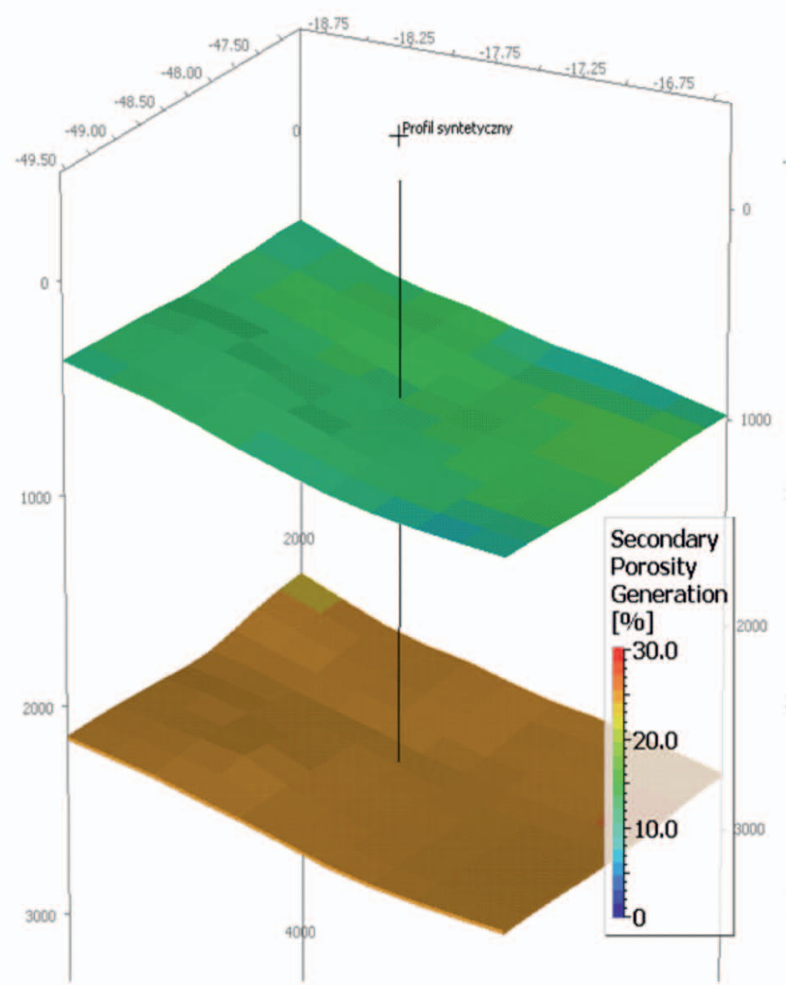

czone w najbardziej optymistycznym modelu, wynoszą średnio prawie $9 \mathrm{~m}^{3}$ metanu na $1 \mathrm{~m}^{3}$ węgla.

W dwóch modyfikacjach modelu bazowego przyjęto założenia, które odtwarzały przebieg procesów naftowych w wyższym od modelu bazowego reżimie termicznym. W modelu GZW_2 wynikał on z założenia wyższego strumienia cieplnego, natomiast w modelu GZW 4 z większego pogrążenia, co dodatkowo skutkowało wzrostem ciśnień. W obydwu przypadkach otrzymano bardzo podobne wyniki. W wyniku symulacji tych modeli uzyskano wyższy stopień realizacji początkowego potencjału węglowodorowego (70\%) niż w modelu bazowym (60\%), lecz niższe ilości metanu zaadsorbowanego, przy czym w modelu zakładającym wyższy reżim ciśnień ilości te są większe, co zgodne jest z ogólnymi prawami fizyki.

Najbardziej obiecujące wyniki uzyskano przy założeniach dokonanych w modyfikacji GZW_3. Przyjęto w niej obecność węgli o wyższym potencjale węglowodorowym $\mathrm{HI}_{0}$, podniesionym w stosunku do pozostałych modeli do $300 \mathrm{mg} \mathrm{HC} / \mathrm{g}$ TOC (o 50\%). W wyniku symulacji uzyskano ten sam stopień realizacji początkowego potencjału węglowodorowego, ale o około 50\% większą ilość węglowodorów wygenerowanych, a tym samym również większą porowatość wtórną (organiczną) węgli. Jeśli chodzi o ilości węglowodorów zakumulowanych, to przewyższają one o blisko $100 \%$ wartości w pozostałych modelach. Jest to efekt zwiększenia przestrzeni akumulacyjnej w pokładach węgla, wynikający

Rys. 9. Wykształcenie porowatości wtórnej w węglach o różnych wartościach wskaźnika $\mathrm{HI}_{0}$ przy założeniu jednakowych reżimów termicznych. Po lewej: pokłady 412 i 905 z modelu GZW_3, po prawej: te same pokłady modelu bazowego GZW_0 
z większej porowatości wtórnej węgli o wyższym wskaźniku $\mathrm{HI}_{0}$ (rysunek 9).

Wykonanie modelowań uwzględniających różne hipotetyczne scenariusze ewolucji basenu i porównanie ich wyni- ków pozwala ocenić wpływ poszczególnych parametrów na przebieg procesów naftowych i daje cenne wskazówki w predykcji stref perspektywicznych, w kontekście prospekcji złóż węglowodorowych.

\section{Podsumowanie i wnioski}

Realizacja opracowania pozwoliła na adaptację i sprawdzenie metody modelowania systemów naftowych do bilansowania metanu w pokładach węgla CBM. W efekcie oszacowano jednostkowy potencjał zasobowy CBM wybranego fragmentu niecki GZW. Wyniki symulacji wykazują, że jest on bardzo duży:

1. Pokłady węgla zalegające na tym obszarze mogą kumulować nawet do $5 \mathrm{mld}^{3}$ metanu, który występuje w nich $\mathrm{w}$ postaci zaadsorbowanej, co daje $800 \mathrm{mln} \mathrm{m}^{3}$ metanu na $1 \mathrm{~km}^{2}$ i prawie $9 \mathrm{~m}^{3}$ metanu na $1 \mathrm{~m}^{3}$ węgla.

2. W sprzyjających warunkach strukturalno-tektonicznych możliwe jest występowanie akumulacji wolnego metanu w przestrzeni porowej węgla, a ich ilości mogą być do 5 razy wyższe niż gazu zaadsorbowanego.

3. Wykazano możliwość i uwarunkowania obecności wielohoryzontowych akumulacji gazu w utworach klastycz- nych zalegających pomiędzy pokładami węgla. Typ akumulacji będzie zależał od właściwości kolektorskich skał. Z uwagi na ich niskie porowatości prognozuje się raczej występowanie złóż niekonwencjonalnych typu tight w utworach mułowcowo-piaszczystych.

Wyciąganie wniosków dotyczących potencjału zasobowego CBM niecki GZW w skali regionalnej na podstawie wykonanej pracy jest przedwczesne - z uwagi na skomplikowaną budowę niecki - i wymaga znacznego poszerzenia obszaru badań oraz zakresu danych wejściowych, które umożliwią lepsze rozpoznanie jej budowy.

Sporządzenie bilansu potencjalnych zasobów metanu w karbońskich utworach niecki GZW oraz wyznaczenie optymalnych stref do poszukiwań może stanowić zachętę dla inwestorów do podjęcia prac prospekcyjnych.

Prosimy cytować jako: Nafta-Gaz 2017, nr 10, s. 739-749, DOI: 10.18668/NG.2017.10.03

Artykuł nadesłano do Redakcji 29.12.2016 r. Zatwierdzono do druku 6.06.2017 r.

Artykuł powstał na podstawie pracy statutowej pt.: Dynamiczne, przestrzenne (4D) modelowanie karbońskiego systemu naftowego GZW celem oceny potencjału zasobowego CBM oraz możliwości występowania akumulacji gazu ziemnego typu tight gas w formacjach piaskowcowo-mułowcowych - praca INiG - PIB na zlecenie MNiSW; nr zlecenia: 107/SG, nr archiwalny: DK-4100-97/2016.

\section{Literatura}

[1] Al-Hajeri M.M. et al.: Basin and Petroleum System Modeling. Oilfield Review Summer 2009, vol. 21, nr 2, s. 14-29.

[2] Allen P.A., Allen J.R.: Basin analysis - principles and applications. Blackwell Sci. Publ., Oxford 1990.

[3] Botor D.: Ewolucja stopnia uwęglenia utworów górnokarbońskich w obszarze górniczym ,Janina” w Libiążu we wschodniej części Górnośląskiego Zagłębia Węglowego (GZW). Geologia 2009, t. 35, s. 105-113.

[4] Chattaraj S., Mohanty D., Kumar T., Halder G.: Thermodynamics, kinetics and modeling of sorption behaviour of coalbed methane - A review. Journal of Unconventional Oil and Gas Resources 2016, vol. 16, s. 14-33.

[5] Flores R.M.: Coal and coalbed gas: fueling the future. Newnes 2013.

[6] Hantschel T., Kauerauf A.I.: Fundamentals of Basin and Petroleum Systems Modeling. Springer 2009.

[7] Karwasiecka M.: Porównanie środowiska geotermicznego w obrębie basenów węlonośnych Lubelskiego i Górnoślaskiego Zagłębia Węglowego. Geologia 2008, t. 34, s. 335-357.

[8] Klent T.R., Charpentier R.R., Cook T.A.: Overview of Assessment Methodologies of Continuous Gas Accumulations. AAPG Geosciences Technology Workshop: Assessment of Unconventional Gas Resources, Istanbul, 24-26.05.2010.

[9] Kosakowski P., Botor D., Kotarba M.: Próba oceny wielkości erozji $i$ warunków paleotermicznych w GZW. [W:] Ney R.,
Kotarba M. (red.): Opracowanie modeli oraz bilansu generowania i akumulacji gazów w serii węglonośnej GZW. Wydawnictwo CPPGSMiE PAN, Kraków 1995, s. 41-51.

[10] Krooss B.M., Leythaeuser D., Lillack H.: Nitrogen-rich natural gases. Qualitative and quantitative aspects of natural gas accumulation in reservoirs. Erdöl und Kohle, Erdgas, Petrochemie vereinigt mit Brennstoff-Chemie 1993, vol. 46, nr 7-8, s. 271-276.

[11] PetroMod Time-Scale Editor (International Stratigraphic Chart, according to the International Commission on Stratigraphy, 2008).

[12] Plewa S.: Rozklad parametrów geotermalnych na obszarze Polski. Wydawnictwo Centrum Podstawowych Problemów Gospodarki Surowcami Mineralnymi i Energią PAN, Kraków 1994.

[13] Probierz K.: Petrologia węgla w rozpoznawaniu węli koksowych rejonu Jastrzębia. Górnictwo i Geologia 2012, t. 7, z. 3, s. 87-117.

[14] Probierz K., Komorek J., Lewandowska M.: Charakterystyka zmian sktadu petrograficznego węla z KWK Zofiówka. Górnictwo i Geologia 2006, t. 1, z. 3, s. 67-79.

[15] Profile Głębokich Otworów Wiertniczych - Ruptawa IG-1.

[16] Sowiżdżał K., Słoczyński T.: Dynamiczne modelowanie systemów naftowych $4 D$ w wybranych strefach basenu battyckiego w rozpoznawaniu złóż węglowodorów w formacjach łupkowych. 
Nafta-Gaz 2016, nr 12, s. 1018-1027, DOI: 10.18668/ NG.2016.12.02.

[17] Sowiżdżał K., Słoczyński T., Matyasik I., Stadtmüller M.: Analiza paleozoicznego systemu naftowego $w$ strefie brzeżnej nasunięcia Karpat fliszowych. Nafta-Gaz 2015, nr 9, s. 632-646.

[18] Turcotte D.L.: On the thermal evolution of the Earth. Earth and Planetary Science Letters 1980, vol. 48, s. 53-58.

[19] Uffman A.K., Littke R.: 3D petroleum systems modeling of North German Basin. First Break 2011, vol. 29, no. 6, s. 49-63.

[20] Welte D.H., Horsfield B., Baker D.R. (eds.): Petroleum and basin evolution: insights from petroleum geochemistry, geology and basin modeling. Springer, New York 1997.

[21] Wygrala B.P.: Integrated study of an oil field in the southern

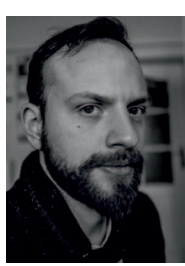

Mgr inż. Arkadiusz DROZD

Specjalista inżynieryjno-techniczny w Zakładzie

Geologii i Geochemii.

Instytut Nafty i Gazu - Państwowy Instytut Badawczy

ul. Lubicz 25 A

31-503 Kraków

E-mail: arkadiusz.drozd@inig.pl
Po Basin, Northern Italy. PhD thesis 1989, University of Cologne, Germany.

[22] Yalcin M.N., Lietke R., Sachsenhofer R.F.: Thermal history of sedimentary basins. [W:] Welte D.H., Horsfield B., Baker D.R. (eds.): Petroleum and basin evaluation. Springer, Berlin 1997, s. $71-168$.

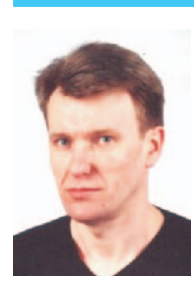

Mgr inż. Tomasz SŁOCZYŃSKI

Główny specjalista inżynieryjno-techniczny

w Zakładzie Geologii i Geochemii.

Instytut Nafty i Gazu - Państwowy Instytut Badawczy

ul. Lubicz 25 A

31-503 Kraków

E-mail: tomasz.sloczynski@inig.pl

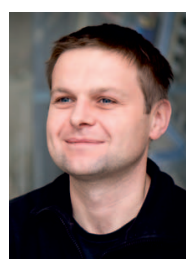

Dr inż. Krzysztof SOWIŻDŻAł

Adiunkt w Zakładzie Geologii i Geochemii.

Instytut Nafty i Gazu - Państwowy Instytut Badawczy

ul. Lubicz 25 A

31-503 Kraków

E-mail: krzysztof.sowizdzal@inig.pl

\section{OFERTA}

\section{ZAKŁAD GEOFIZYKI WIERTNICZE]}

Zakres działania:

- badania tomograficzne skał:

» trójwymiarowa wizualizacja i analiza wewnętrznej struktury przestrzeni porowej skał metodą mikrotomografii rentgenowskiej (micro-CT),

tomografia metrowych odcinków skał, profilowanie zmian parametrów petrofizycznych rdzenia (porowatość, gęstość objętościowa):

- badania metodą jądrowego rezonansu magnetycznego:

" określanie rozkładu nasycenia wodą przestrzeni porowej próbek,

" generacja map T1-T2, szacowanie nasycenia woda/węglowodorami, identyfikacja obecności substancji organicznej TOC;

- oznaczanie jakościowego i ilościowego składu mineralnego skał oraz wydzielonej frakcji ilastej na podstawie analizy rentgenowskiej;

- $\quad$ wyznaczanie zawartości naturalnych pierwiastków promieniotwórczych: uranu, toru i potasu w skałach, płuczkach wiertniczych i materiałach budowlanych;

- $\quad$ ocena elektrycznych parametrów skał (wskaźnika struktury porowej i zwilżalności);

- określanie zależności elektrycznej oporności właściwej płuczek wiertniczych od temperatury

- ocena prędkości propagacji fal ultradźwiękowych w skałach, kamieniach cementowych i płuczkach wiertniczych;

- badanie przewodności cieplnej skał;

- $\quad$ wyznaczane współczynnika przepuszczalności

- $\quad$ badanie gęstości, gęstości właściwej i porowatości:

- $\quad$ interpretacja profilowań geofizycznych w zakresie oceny stanu zacementowania rur okładzinowych w otworach;

- badania serwisowe:

» analiza chemiczna skał metodą fluorescencji rentgenowskiej;

" spektrometryczne pomiary gamma na rdzeniu wiertniczym: ${ }^{40} \mathrm{~K},{ }^{238} \mathrm{U},{ }^{232} \mathrm{Th}$, total gamma przy wykorzystaniu mobilnego urządzenia "Gamma Logger".

Kierownik: dr inż. Marek Dohnalik

Adres: ul. Bagrowa 1, 30-733 Kraków

Telefon: 126506770

Faks: 126177470,126531665

E-mail: marek.dohnalik@inig.pl 